\title{
Provincial treatment and care asylums for the mentally ill in East Prussia as forgotten cultural heritage: case study of the asylum in Allenberg (now Znamensk, Russian Federation)
}

Zarys treści: Artykuł dotyczy problematyki ukazującej rolę architektury w rozwoju pruskiej psychiatrii w XIX i na początku XX w. Na przykładzie Prowincjalnego Zakładu Leczniczo Opiekuńczego w Allenbergu (ob. Znamiensk, Federacja Rosyjska) pokazano percepcję wzorcowych rozwiązań pruskich azylów na prowincji. Badany zespół spełniał ówczesne wymogi, dowodząc, że wzorce i nowoczesne tendencje docierały tu z wiodących ośrodków bardzo szybko. Zespół azylu w Allenbergu stanowił świadectwo rozwoju pruskiej i europejskiej myśli architektonicznej służącej medycynie. Niestety obecny stan budynków dawnego azylu jest bardzo zły, a cały zespół traktowany jest raczej jako niechciane dziedzictwo niż cenny zabytek kulturowy.

Content outline: The article focuses on issues demonstrating the role of architecture in the development of Prussian psychiatry in the nineteenth and the early twentieth century. The Provincial Treatment and Care Institution Allenberg (now Znamensk, Russian Federation) is used as a case study to demonstrate the perception of model solutions used in Prussian asylums located in distant provinces. The asylum discussed in this article met the contemporary requirements, proving that these models and newest trends reached East Prussia very quickly. The asylum complex in Allenberg was a testimony to the development of Prussian and European architectural thought in the service of medicine. Unfortunately, today the former asylum remains in a poor condition and is treated as unwanted legacy rather than a cultural monument.

Słowa kluczowe: architektura XIX i początku XX w., zakłady psychiatryczne w Prusach, Prusy Wschodnie, Allenberg, Europa Wschodnia, Rosja, Znamiensk

Keywords: nineteenth and early twentieth century architecture, lunatic asylums in Prussia, East Prussia, Allenberg, Eastern Europe, Russian Federation, Znamensk

\section{Introduction}

The late eighteenth and early nineteenth century was a time of major social and economic changes and development of science and medicine, which among others 
led to recognising "madmen" as people afflicted with mental illness. Early attempts were made to treat these unfortunates, no longer limited to care and isolation. Due to the so-called "moral therapy," the approach to the sick changed radically. Severe restraints and corporal punishments were abandoned; instead, doctors tried to treat patients kindly and appeal to their moral sense. The main therapy methods included conversation, persuasion, manual labour, and entertainment. The objective was to balance the nervous system and straighten up human minds through humanitarian treatment, changes in life conditions, beneficial and harmonious surroundings, physical and mental activity, and suitable employment. ${ }^{1}$ Psychological theories based on beliefs of, among others, Locke and Condillac or William Battie, helped promote the ideals of disciplined order and social rehabilitation. ${ }^{2}$ In his work Della pazzia in genere e in specie (1793-1794), based on his experiences as a mental hospital doctor, the Italian physician Vincenzo Chiaruggi argued that the role of "bedlams" was not only to isolate the mentally ill, but also to treat them, and was the first to write down the regulations of an asylum for the demented. ${ }^{3}$ Philippe Pinel, a French doctor working at the Bicêtre hospital, reduced the use of mechanical restraints, achieving positive results. Based on his work in the Belhomme, Bicêtre and Salpêtrière hospitals, in 1801 he published a manual ${ }^{4}$ in which he opposed treating madmen like wild beasts. He believed they could be "educated" like children in order to "develop and strengthen their mental faculties." Calling his approach moral therapy, he appealed for its introduction in hospital wards. Pinel's manual gained considerable renown and the doctor is now regarded as the father of modern psychiatry. ${ }^{5}$

To this end, specialist hospitals and care homes solely for the mentally ill began to be founded. One of the basic ideas of early psychiatrists was to provide their patients with "mindful" care and decent life conditions. Attempts were made to have asylum patients feel at home, allow them to work, offer them entertainment, and give them an opportunity to practice their faith. According to this idea, wellplanned architecture was to support treatment and together with its surroundings allow to use erstwhile state-of-the-art therapeutic methods. ${ }^{6}$

${ }^{1}$ For more on this, see E.L. Shorter, Historia psychiatrii. Od zakładu dla obłąanych po erę Prozacu, Warszawa, 2005, pp. 31-33; L.C. Charland, "Science and Morals in the Affective Psychopathology of Philippe Pinel," History of Psychiatry, 21 (2010), no. 1, pp. 38-53.

2 R. Porter, The Greatest Benefit to Mankind: A Medical History of Humanity, London, 1997, pp. 272-273; Shorter, op. cit., pp. 19-20.

3 Ibid., p. 21.

${ }^{4}$ P. Pinel, Traité médico-philosophique sur l'aliénation mentale, 2nd ed., Paris, 1809, https://gallica. bnf.fr/ark:/12148/bpt6k76576g.texteImage (accessed: 29 March 2020).

${ }^{5}$ Shorter, op. cit., pp. 21-22.

${ }^{6}$ B. Edington, "The Well-Ordered Body: The Quest for Sanity through Nineteenth-Century Asylum Architecture," CBMH/BCHM, 11 (1994), pp. 375-386. 
Due to the peculiar nature of mental disorders, designing establishments for the mentally ill was a very complicated enterprise. The sick stayed in the asylum for a long time, sometimes until death. In addition, they were usually able-bodied, allowing therapy through work or other activities. Attempts were also made to ensure that inmates could continue to lead "normal" lives similar to those before the onset of the illness. However, mental institutions also housed dangerous patients who required constant supervision. All those specific factors called for architectural solutions that greatly differed from those used in general hospitals or other medical facilities.

In the nineteenth century, especially in its second half, the spatial arrangements of entire estates and the architectural forms and functional layouts of buildings were modified to make them more suitable for psychiatric requirements. This evolution can be clearly observed in provincial treatment and care institutions for the mentally ill in Prussia. ${ }^{7}$ Suitably designed functional layouts of the estate as a whole and of each individual facility were an attempt to properly organise the life of the patient community. The Prussian state took care to develop the asylums functionally, fostering cooperation between renowned architects and experienced psychiatrists. Model facilities were built according to recommendations and widely discussed in professional literature. ${ }^{8}$

Provincial treatment and care institutions for the mentally ill were established in all provinces of the Kingdom of Prussia (the German Empire since 1871), including in the peripheral region of East Prussia. The question arises whether state-of-theart models were used only in leading institutions or managed to spread to remote corners of the country. How swiftly did "modern medical and technical thought" travel to the outskirts of the Prussian state? This question prompts another: what was the fate of hospital complexes in areas ceded to another state after the Second World War - are they now monuments preserving the material culture and medical thought of their times, or an unwanted legacy left behind by a foreign culture?

East Prussia hosted three provincial care and treatment institutions for the mentally ill. The oldest of them, Provinzial Heil- und Pflegeanstalt Allenberg, was opened in 1852 and located in Allenberg, ${ }^{9}$ two kilometres to the south of Wehlau (today Znamensk, Russian Federation). ${ }^{10}$ Another asylum, Provinzial Heil- und

7 For more on the evolution of architectural and spatial layouts of Prussian asylums, see D. Bręczewska-Kulesza, Architektura w służbie medycyny. Ewolucja układów architektoniczno-urbanistycznych szpitali dla psychicznie chorych na przykładzie pruskich prowincjalnych zakładów leczniczo-opiekuńczych w XIX i początku XX w., Bydgoszcz, 2020.

${ }^{8}$ Ibid., pp. 50-62.

9 Because this article discusses Prussian times, German names of localities in which the asylums were founded will be used from now on.

${ }^{10}$ H. Laehr, Die Anstalten für Psychisch-Kranke in Deutschland, Deutsch-Österreich, der Schweiz und den Baltischen Ländern, Berlin, 1907, pp. 2-3. 
Pflegeanstalt Kortau bei Allenstein in Ostpreussen, opened for use in 1886, was located in Kortau (now Kortowo, a quarter of Olsztyn, Poland). ${ }^{11}$ The third one, Provinzial Heil- und Pflegeanstalt Tapiau, operated since 1901 in Tapiau (now Gvardeysk, Russian Federation, Tapiewo in Polish), opened in a former ward for mentally ill criminals at the local house of correction. ${ }^{12}$ All these institutions were operated according to combined care and treatment hospital concept devised by Christian Roller in the 1830s, which was the usual approach for institutions run by the state. ${ }^{13}$ All were state-of-the-art, specially planned and built facilities, offering architectural forms that matched the conceptual framework of nineteenth century psychiatry. The oldest of them, the Allenberg asylum, can be used to trace the development of this kind of architecture since the mid-nineteenth to the early twentieth century.

\section{The establishment of the Allenberg asylum}

Provinzial Heil- und Pflegeanstalt Allenberg was erected according to a model design developed by a psychiatrist, Professor Heinrich Damerow. ${ }^{14}$ The design was used as a foundation for construction plans drafted by master builder Gustav Spott. The psychiatrist acted on request of the royal construction committee. The idea was to establish a new, model treatment and care institution for the mentally ill. Damerow's original idea was meant for a facility in Nietleben near Halle, whose first stage of construction was completed in 1844. The investment must have turned out well, because just four years later, in 1848, the same model, with minor changes, was used to build the Allenberg institution. ${ }^{15}$ On the medical side, the construction was supervised by the institution's first director, Carl Reinold Bernhardi. ${ }^{16}$ The design or its variants was also used to plan many

11 A. Stoltenhoff, "Provinzial-Heil- und Pflegeanstalt Kortau bei Allenstein in Ostpreussen," in: Deutsche Heil- und Pflegeanstalten für Psychischkranke in Wort und Bild, ed. J. Bresler, vol. 1, Halle a. Saale, 1912, pp. 176-177.

12 F. Hoppe, "Die Pflegeanstalt für geisteskranke Männer zu Tapiau Ostpr.," Psychiatrisch-Neurologische Wochenschrift, 11 (12 June 1904), pp. 101-106.

13 In a 1831 publication, Roller offered the basic principles for planning asylums of the new type: Ch.F.W. Roller, Die Irrenanstalt nach allen ihren Beziehungen, Karlsruhe, 1831.

14 Prof. Heinrich Damerow (1798, Stettin - 1866, Halle-Nietleben) was the first director of the Halle-Nietleben institution. He graduated in medicine in Berlin and worked there for a number of years in the medical department of the Ministry of Culture and Education. He was one of the founders of the Allgemeine Zeitschrift für Psychiatrie journal (W. Leibbrand, "Damerow, Heinrich Philipp August," in: Neue Deutsche Biographie, Bd. 3. Berlin, pp. 498-499, available at https://www.deutsche-biographie.de/sfz9242.html (accessed: 20 April 2020).

15 O. Peters, Heino Schmieden. Leben und Werk des Architekten und Baumeisters 1835-1913, Berlin, 2016, p. 354.

16 Ibid., p. 354. 
other facilities, for example in Owinsk (now Owińska), Schwetz (now Świecie) or Kurmark. ${ }^{17}$

Following the idea of isolating the sick in a "rural idyll," the hospital complex was situated in the middle of a wide, green expanse, on the left bank of the Alle river (Polish: Łyna, Russian: Lava), in a spot which Bernhardi claimed was "one of the most charming neighbourhoods of our province." 18

The facility's buildings were laid out in the form of a generally tight rectangular block whose four corners housed wards for patients. The south-western side held wards for women and the opposite, north-eastern one for men. The entrance to the asylum, on the north-west, featured an administrative building, behind which a set of service buildings was erected. The wards for the sick were complemented by two buildings with solitary cells for "agitated madmen."

Like in Halle, the buildings of both the male and the female ward were separated into sections for "treatment" of patients deemed curable and "care" for the terminally insane. On both sides, the treatment section was divided into three sections: calm patients "from the educated classes," calm patients "from the uneducated classes," and agitated patients. A fourth ward for the terminally ill and epileptics was located in the care section. The two-storey buildings for patients were aligned along corridors, with patient rooms located on the outside to provide a pleasant view of the surrounding countryside, while the corridors were oriented towards the yard. The buildings featured bedrooms with four, eight, and twelve beds as well as solitary cells for strongly agitated patients who required immediate isolation. The corners housed day rooms, billiard rooms, or musical salons, with staff premises on the ground floor. Safety was provided through fire hydrants. The rooms were lighted with gas supplied by the local coal-based gas plant and heated with heating pipes carrying warm air, which were also installed along some of the corridors. Living quarters for the facility's staff were located on the underground floor. ${ }^{19}$ On the south-eastern side, behind buildings with care wards, two structures were situated, each with ten cells along a corridor, for patients requiring longer periods of isolation.

17 Both Spott and Damerow published their observations on the construction of the Halle institution: G. Spott, "Die Provinzial-Irrenanstalt zu Halle," Zeitschrift für praktische Baukunst, 5 (1854), pp. 153-157; H. Damerow, "Zur Geschichte des Neubaues der Ständischen Irren- Heil -und Pflege-Anstalt für die Preuss. Provinz Sachsen bei Halle a. d. S.," Allgemeine Zeitschrift für Psychiatrie und psychisch-gerichtliche Medizin, h. 1 (1844), pp. 97-112. The institution was also mentioned in a Viennese medical journal by M. Viszánik, Die Irrenheil- und Pflegeanstalten Deutschlands, Frankreichs, sammt der Cretinen-Anstalt auf dem Abendberge in der Schweiz, vol. 1, Vienna, 1845, pp. 67-71.

${ }^{18}$ C.R. Bernhardi, "Provinzial-Irrenheil- und Pflegeanstalt Allenberg bei Wehlau," Allgemeine Zeitschrift für Psychiatrie und psychisch-gerichtliche Medizin, 4 (1854), p. 679.

19 C.R. Bernhardi, "Die Heil- und Pflege-Anstalt Allenberg bei Wehlau in Ostpreussen," Correspondenz-Blatt der Gesellschaft für Psychiatrie und Gerichtliche Psychologie, 1 (5) (1 September 1854), pp. 33-35. 
Between the "treatment institution" buildings for curable patients there was an administrative edifice whose sides featured roofed gateways leading to the male and female sides of the asylum. It was a two-storey building with a three-storey projection covered by a separate gable roof. The ground floor housed the reception area, offices, cash desk, visitor quarters, and the inspector's apartment. The first floor included a conference room and the director's apartment. The last floor, in the wide projection section, held a ballroom with an antechamber. Additional light was let inside by tall, large windows which marked it out on the projection's façade. In Damerow's Halle design, the administrative building was located in the same spot, but its functional layout was different. Unlike its counterpart in Allenberg, it had three full floors. The ground floor zones were laid out similarly in both buildings. In Halle, the first floor was occupied by the director's apartment, another small apartment for the pastor, rooms for convalescing patients, reading room, billiards room, kitchen, and toilets. ${ }^{20}$ Equipping the institution with a room that could be used for events, dances, and perhaps concerts or performances, ${ }^{21}$ as was the case in Allenberg, was a very cutting-edge solution which gained more popularity in the third quarter of the nineteenth century and came in common use on the cusp of the twentieth. In addition, the underground floor housed an apartment for the gatekeeper, laundry, and service rooms. ${ }^{22}$

On the opposite side, behind the two wings housing care wards, pavilions with solitary cells for agitated patients were located, connected to the wards via roofed skybridges, with a slightly different orientation than in Halle.

The interior of the estate was occupied by a large set of service buildings whose layout was similar to the letter "T." The buildings, with varying shapes, were shadowed by a tower rising over the institution. The ground floor of the elongated body of the building housed, from the north-western side, the bakery, kitchen, laundry, and dish cleaning room. The first floor was occupied by a drying room (a quick drying chamber, probably equipped with devices that pumped in warm air), laundry storerooms, ironing room, a few apartments for staff, and a huge water tank. The cellar held a steam boiler serving the kitchen and laundry, as well as storerooms. A perpendicular branch of the building (on the southern side) had a "double" bathing facility on the ground floor, with separate sections for men and women, as well as a ward for bedridden patients. The baths consisted of cloakrooms, bathrooms, and shower stalls which were also used for steam baths. In addition, bathrooms contained bathtubs separated by curtains. Separate baths were located in buildings housing the "madmen" cells. The first floor was planned to contain a laboratory, drugstore, and the apartments of the two assistant deputy

\footnotetext{
${ }^{20}$ Spott, op. cit., pp. 153-154.

${ }^{21}$ Bernhardi, Die Heil- und, p. 34; V. Titius, "Zur Geschichte der Heil- und Pflegeanstalt Allenberg bei Wehlau," Wehlauer Heimatbrief, 56 (1996/1997), p. 58. Unfortunately, these articles do not mention whether the room featured a stage.

${ }^{22}$ Bernhardi, Die Heil- und, p. 35.
} 
doctors. The cellar was set aside for service rooms, a morgue with a dissecting room, and apartments for staff. In the middle section, from the south-eastern side, at the intersection of both buildings, there was a projection with three storeys, the last of which housed a chapel. Over the middle of the projection, a clock tower about 110 meters tall was built to loom over the entire institution. ${ }^{23}$ A similar layout, with the chapel located in the service building, was used in the Schwetz asylum erected from 1852 to $1855 .{ }^{24}$ Thanks to its location in the middle of the yard, the set of service buildings could be accessed by the sick from all wards, making staff work easier and allowing patients to be employed in various service functions. The spacious underground floors of ward buildings were also planned to contain workshops. The buildings in the complex were connected to each other by roofed passageways. ${ }^{25}$

The external appearance of the buildings was subdued so as to avoid disturbing the patients, which was in keeping with contemporary psychiatric recommendations. ${ }^{26}$ The simple shapes of the buildings were enhanced only by wide, side-hanging plastered projections, topped by high gable roofs. An additional modest architectural detail were sectioned cornices over windows and friezes made of rowlock course brick (currently plastered over, but originally probably contrasting with the light plaster around them). In addition, the projections were flanked by stylised columns in the corners. Richer decoration was only used to accentuate the more important spots of the buildings, like the southern façade of the service building whose wide projection housed the chapel on the third floor. The middle of the projection was highlighted by a high tower whose floors were separated by brick cornices and intersected by lesenes. At the level of the chapel, a skylight in the form of a Latin cross was placed. On both sides of the tower, the chapel was marked out using high, arched windows similar to triforia. The crown of the projection was decorated with brick belts and arcade friezes made of rowlock course brick, contrasting with the surrounding light plaster. More attention was devoted to the edifice of the administrative building, with large, middle-placed projections flanked by stylised columns on the southern and northern façade. On the northern side, at the front, the sides of the building featured entrances to the institution in the form of roofed gates with wood carvings, and the projection sported a decorative portal at the entrance to the building. On the third storey, the ballroom was set out by high, top-arched windows crowned by a row of jerkin heads. ${ }^{27}$

${ }^{23}$ Bernhardi, Die Heil- und, pp. 34-35.

${ }^{24}$ E. Römer, "Irren-Anstalt zu Schwetz," Zeitschrift für Bauwessen, 3-4 (1854), tables 31 and 36.

${ }^{25}$ Bernhardi, Die Heil- und..., pp. 33-35.

${ }^{26}$ L. Förster, "Über den Bau und Organisation der Irrenanstalten," Allgemeine Bauzeitung, 8 (1855), pp. 318-319.

27 On the Neo-Romanesque design of buildings, see И.В. Белинцева, “Архитектурный комплекс бывшей психиатрической лечебницы в Алленберге,” in: Калининградские apхивы, vol. 9, Калининград, 2011, pp. 35-48; the same author also discussed the Allenberg asylum in one of 
Psychiatrists recommended that patients spend time outdoors, and therefore efforts were made tried to establish a garden for each ward. In Allenberg, the ward gardens were located outside the estate, adjacent to each building and surrounded by fencing. The wards and solitary cells were separated by a strolling lane fronted by a woodyard. Next to the laundry was a yard used to bleach linen (Bleichplatz) with a pump. The ward gardens were flanked on the side of the female ward by a vegetable garden, probably tended by the patients, and on the other side by the entrance to the machine room. A decorative lawn was found in front of the director's building, flanked by the director's and inspector's garden on both sides. The buildings were connected by roofed corridors. ${ }^{28}$

The institution was well equipped with the latest technological advances. Next to the river was a mill whose engine was used to pump water out of the depth of forty meters and distribute it through the facility by means of a water tower. Steam heating was installed in the kitchen, laundry, and baths. A small steam engine located in the service building powered a spinner and dryer. The institution had a lighting installation powered by gas from the nearby gas works. The burners used to provide light were suspended high overhead, on movable lines, out of the reach of the patients..$^{29}$ Potable water was supplied by five deep water wells. ${ }^{30}$ Due to proximity to a river, supply of goods was planned to be carried out by boat. ${ }^{31}$ Dr Bernhardi also pointed to the issue of lighting the rooms from the outside; the windows used for this purpose had to be safe for the patients. Installing outside bars could not be avoided, but following the recommendations of contemporary psychiatry, care was taken to make them as unnoticeable as possible to prevent the patients from feeling shut in. For this reason, diamond-shaped bars were chosen. In wards for the agitated, the bottom half of the windows had to be reinforced with a wire mesh after a few months, because the patients repeatedly broke the panes. ${ }^{32}$

The original version of the institution was built according to contemporary views on asylum architecture. It provided patients with suitable conditions in architectural terms, as recommended by the ministry, contemporary knowledge and skills, and standards developed by German and European psychiatrists and architects. It was equipped with the necessary technology, workshops, baths, chapel, ballroom, its own bakery, and gardens. However, because the number of patients was increasing from year to year, the existing complex had to be expanded.

the chapters of the monograph, И.В. Белинцева, Архитектура Восточной Пруссии: факты и интерпретации. Калининградская область, Калининград, 2020, pp. 208-216.

${ }^{28}$ Bernhardi, Die Heil- und..., pp. 33-36.

${ }^{29}$ Ibid., p. 35.

30 Titius, op. cit., p. 60.

31 Bernhardi, Provinzial, p. 679.

32 Id., Die Heil- und, p. 35. 


\section{The expansion of the asylum}

According to the original design, the asylum was to house 250 patients, a number that soon proved insufficient. As a result, expansion began in the 1870s: new wards for the sick were located in free-standing pavilions erected in the park to the east of the original estate. The first expansion took place from 1870 to 1872 . Designing the pavilions was entrusted to a pair of renowned Berlin architects, Martin Gropius and Heino Schmieden. ${ }^{33}$

At that time, two free-standing, two-storey buildings with three-storey projections in the middle and adapted lofts were erected. These facilities were meant to house 200-250 patients. The two lower storeys housed the sick in need of extra care - the invalid and "soiling" ones. The top storey was set aside for those calm, incurable patients who were able to work and for this reason spent most of their day outside of the ward. The buildings were, as a rule, designed without corridors, and rooms for the sick were arranged one next to another. The axes of the buildings featured wide projections which contained the entrance and staircases on one side and toilets/washrooms or baths on the other, with day rooms opposite them, behind a short corridor. Directly connected bedrooms, entered from the stairs via staff rooms, were placed on both sides of the day rooms. All premises had good, cross-ventilated airflow and were equipped with airborne heating. The buildings were equipped with gas and water installations. ${ }^{34}$

Thanks to their rustic character, the free-standing pavilions were more in concord with the greenery of the park than the original brick buildings. The facilities, with varying shapes, were topped with multi-hipped roofs and had their façades covered with red brick veneer. The ground floor had patios that connected the buildings with the garden and allowed patients to easily move in and out of the day rooms. Such solutions were often used in asylums dating from the last quarter of the nineteenth century and recommended in professional literature. ${ }^{35}$ The bucolic nature of the buildings was additionally underscored by wooden pieces placed in the crowns and porch structure and guardrails. Each pavilion was adjacent to a fenced ward garden. ${ }^{36}$ In addition, the pavilions were surrounded by gardens, and the whole complex was located in the middle of a park. The enfilade design of the buildings likewise followed the new trends so as to use space as efficiently as possible. Such layouts were recommended especially for care wards. Rustic villa shapes, façades covered by red brick veneers, porches, and balconies became

33 Peters, op. cit., p. 355; A. Körte, Martin Gropius. Leben und Werk eines Berliner Architekten 1824-1880, Berlin, 2013, p. 296.

34 Peters, op. cit., p. 355.

35 N.A. Funk, "Irren-Anstalten," in: Handbuch der Architektur, ed. J. Durm, 4, Halb-Band 5, Heft 2, Darmstadt, 1891, pp. 9-22.

36 The building design choices were discussed in more detail by Körte, op. cit., pp. 295-296. 
popular in asylum architecture. Buildings in a similar style were also erected in Halle when that institution was expanded. ${ }^{37}$

Introducing small, free-standing pavilions was another stage of development in asylum architecture, but also in general hospital architecture, related to the mid-nineteenth century state of knowledge about diseases spreading by means of pathogens. Through observation and medical statistics, it was demonstrated that patients staying in different wards of the same hospital building were prone to the same diseases, which were most probably transmitted by the staff. In 1883, bacteriological standards were officially introduced in German clinical medicine, leading to the rise of the pavilion hospital model in order to protect the sick against the transmission of pathogens. ${ }^{38}$ The first pavilion-style Berlin hospital, the Städtisches Krankenhaus im Friedrichsheim designed by M. Gropius and H. Schieden, was erected in 1868-1874. The hospital consisted of free-standing pavilions for the sick as well as administrative and service buildings. ${ }^{39}$ The pavilion layouts in institutions for the mentally ill had an extra importance. It was believed that such solutions would increase intimacy, help build a family-like, friendly atmosphere, and ensure better contact with patients. In the discussion that continued through the entire nineteenth century, the 1870 s brought voices that called for replacing closed layouts with free-standing pavilions. Thus, Gropius and Schmieden were precursors of this trend in institutions for the deranged. ${ }^{40}$ In addition, separate pavilions or, as in Allenberg, rooms in the service building were set aside for infectious patients.

In 1880, the Allenberg institution was expanded to add a farming colony which was located to the south-west of the original estate. The farm consisted of residential buildings for fifty men and ten women as well as a stable, cowshed, pigsties, granary, smithy, and other service buildings. The buildings were designed by the office of district master builder Franz (?) Krah, while the construction was supervised by provincial master builder Wienholdt. The service buildings were fitted with modern equipment to ease work and maintain hygiene. The colony was well-connected to the central part of the institution..$^{41}$ The farm had at its disposal a cultivable area of 91 hectares. In total, the institution owned 250 hectares of land, featuring buildings, a park, gardens, and farming plots. ${ }^{42}$

37 E. Fries (Dr), "Landes- Heil- und Pflege-Anstalt Nietleben bei Halle a. S.," in: Deutsche Heilund Pflegeanstalten für Psychischkranke in Wort und Bild, ed. J. Bresler, vol. 2, Halle a. Saale, 1911, p. 216.

38 Z. Podgórska-Klawe, Od hospicjum do współczesnego szpitala, Warszawa, 1981, pp. 139-158.

39 Körte, op. cit., pp. 277-286; Peters, op. cit., pp. 274-278.

40 A transitional stage between the closed block system and the pavilion layout can be seen in the Neustadt-Eberswalde institution designed by Martin Gropius, erected in 1862-1865 and expanded in 1867/1868 in cooperation with Heino Schmieden. While a system of symmetric blocks was still used, the layout of the side wings already resembled self-standing pavilions (Körte, op. cit., 2013, pp. 140-149; Peters, op. cit., 2016, 351-353).

${ }^{41}$ Белинцева, Архитектурныци, р. 41.

${ }^{42}$ Laehr, op. cit., pp. 2-3. 
As the number of patients rose, employing more personnel, especially nurses, became a must. Accordingly, an employee colony was erected, consisting of a few two-storey houses located about 500 metres from the asylum, on the western side of the hospital complex. ${ }^{43}$ The settlement's streets were arranged in the shape of an isosceles triangle and each building had a small garden in front. The small houses were built with bricks, the top floor (similar to a loft) done in part using half-timbered technology (the so-called "Prussian wall"). The simple, cube-like shapes of the buildings were enhanced with side projections that jutted slightly out of the façade and were covered with gable roofs resting on wooden brackets with decorative carvings. ${ }^{4}$

Subsequent expansions took place in 1891-1895, 1900 and 1906. The number of beds was then increased to about a thousand. Four free-standing pavilions were erected, two for each sex, and in 1906 two quarantine sections for infectious patients, with ten beds each, were completed. In the early twentieth century, about 1907, a villa was also built for the institution's director in the northern part of the estate, next to the river. The design of the house included Art Nouveau and folk motifs fashionable at the time. The greatly diversified shape of the building, with bays, mansards, and façades interleaved with windows of various shapes, was covered by a high, multi-hipped roof. The entire house was laid on a stone foundation and brick plinth, with rough-plastered walls rising above. Modest decoration was made of wood and maiolica. ${ }^{45}$

According to the recommendations of contemporary psychiatrists and the policy of the state, the institution evolved into an independent "hamlet" with its own farm, gardens, carpentry, leather-working, locksmithing, shoemaking and hydraulic workshops, bakery, laundry, and own connection to energy supply. ${ }^{46}$ This allowed to greatly reduce the costs of running the asylum while affording opportunities for the patients to socialise.

\section{The asylum after 1914}

With the outbreak of the First World War, the asylum's patients and staff fell on hard times. During wartime, the institution was forced to rely on whatever its farm could produce. In early August 1914, more than one half of male officials and employees was conscripted, leaving behind nurses and other female staff who remained with the sick during the Russian occupation. ${ }^{47}$ Because of the crisis and the spread of various epidemics, however, many of the patients died, and in

\footnotetext{
43 Titius, op. cit., p. 59.

44 Белинцева, Архитектурный, р. 43.

${ }^{45}$ Ibid., p. 45.

46 Titius, op. cit., p. 59.

${ }^{47}$ Ibid., p. 59, the occupation lasted from 25 August to 10 September 1914.
} 
1918 Allenberg housed just 586 of them. The situation improved after the end of the Great War and the rampant inflation that followed. The complex saw further expansions, among them a building for the agricultural manager and a new ward for men in the park and for women among the gardens. A few of the existing edifices were also enlarged, and service and agricultural buildings modernised. ${ }^{48}$ In 1929 , the institution was able to house 1,400 patients. ${ }^{49}$ The hospital was finally closed down in 1940.

Following the closure, the patients and medical staff were transferred to other institutions in the province. In May 1940, about 1,400 Allenberg patients were moved to the Tapiau and Kortau facilities. Falling victim to "Aktion Lange," 207 of them were deported to the Soldau concentration camp and killed as part of a group of 1,558 prisoners from East Prussian psychiatric hospitals. On 8 June 1940, the Allenberg institution was completely wound up and the remaining patients translated to the Kortau facility, which during Aktion T4 served as a transport hub for moving them further afield to extermination centres such as Prina Sonnenstein. As a result of these activities, about 4,000 patients of East Prussian psychiatric hospitals perished in the years 1940-1942.50

The hospital buildings were taken over by the army. Initially, they were used as barracks by a Waffen SS battalion, while the farm and gardens were leased to the SS economic department in Berlin. In the summer of 1944, the SS vacated the premises, and the institution was used to provide extra wards for hospitals in the region. After the Second World War, the former asylum facilities were seized by the Soviet, later Russian, army. ${ }^{51}$ The institution was for the most part destroyed and today remains largely unused. Unfortunately, this state-of-the-art asylum, built and expanded in line with requirements of the emerging nineteenth century psychiatry, has left behind few traces. Most of the buildings had been abandoned and are tumbling down, others changed their purpose. The institution, for many years a witness to the development of medicine, psychiatry, architecture, and technology, simply disappeared.

\section{Conclusions}

In the nineteenth century, each Prussian province boasted provincial treatment and care institutions for the mentally ill. Their planning and construction followed

\footnotetext{
${ }^{48}$ Ibid., pp. 59-60.

49 Peters, op. cit., p. 355.

50 S. Topp, P. Fuchs, G. Hohendorf, P. Richter, M. Rotzoll, "Die Provinz Ostpreußen und die nationalsozialistische 'Euthanasie': SS - 'Aktion Lange' und 'Aktion T4,'” in: Medizinhistorisches Journal, 43/1, 2008, pp. 20-55, https://elibrary.steiner-verlag.de/article/99.105010/ medhist200801002001 (accessed: 2 May 2021).

51 Titius, op. cit., p. 62.
} 
model hospitals and was guided by recommendations widely discussed in professional journals. According to these guidelines, the spatial layouts of hospital estates evolved from compact block buildings to open arrangements consisting of many small pavilions strewn around gardens and parks. Very often, they were surrounded by gardens and farms in which the patients were employed. Living quarters for the staff rounded up the architecture.

The Provincial Treatment and Care Institution in Allenberg discussed in the article is an excellent example of the development and transformation of asylums in the period under consideration. Although erected in the countryside, far from the leading medical and architectural centres of the day, it met all essential objectives and requirements concerning psychiatric architecture. The facility was built based on the work of eminent authorities in psychiatry and architecture who forged a new path in the development of Prussian asylums. To summarise, it may be stated that the Allenberg asylum complex was a witness to the development of Prussian and European architectural thought in the service of medicine that rapidly spread to the outskirts of the country and was not inferior in the quality of execution to the leading centres.

The lofty idea of improving the fate of "madmen" and attempting to treat them through architecture, among other remedies, was cut short by the Nazi "Aktion T4." From 1939 to 1945, the Nazis killed 200,000 patients of hospitals and psychiatric institutions, adapting hospital complexes for other, usually military, purposes. The asylums that managed to survive and were later reinstated as psychiatric and neurological hospitals operate until this day and remain valuable monuments and relics of the past. ${ }^{52}$ Unfortunately, this was not the post-war fate of the Allenberg institution. The buildings were taken over by the Soviet, later Russian, military, which occupied it until 2013, when the units garrisoned there were dissolved. Earlier, from 2005 to 2009, the chapel located in the former administrative building was renovated thanks to the efforts of East Prussia's Lutheran community, and a small museum was set up on the second storey of the tower. In 2007, by a decree

52 The prime examples of the institutions that continue to serve as psychiatric and neurological hospitals are the Provinzial-Irrenanstalt Ueckermünde, today AMEOS Klinikum Ueckermünde; Provinzial-Irrenanstalt Dziekanka, today the Dziekanka Regional Psychiatric and Neurological Hospital; Provinzial-Irrenanstalt Conradstein bei Pr. Stargard, today the Stanisław Kryzan Psychiatric and Neurological Hospital in Starogard Gdański; Irren-Anstalt der Stadt Berlin zu Dalldorf, today the Karl-Bonhoeffer-Nervenklinik; Irrenanstalt Herzberge der Stadt Berlin in Lichtenberg, today the Evangelisches Krankenhaus Königin Elisabeth Herzberge; and Provinzial-Irrenanstalt Obrawalde bei Meseritz, today the Independent Public Psychiatric and Neurological Hospital in Międzyrzecz. Another interesting example is the Martin Gropius Krakenhaus in Eberswalde, whose main buildings were occupied by the Red Army after the end of the Second World War. The German psychiatric hospital was moved to the service buildings. In 1994, the Russian military abandoned the dilapidated facilities of the former asylum. Renovation and modernisation efforts then began to restore the entire hospital as a psychiatric unit. (Gropius in Eberswalde. MartinGropius-Bau der Landesklinik Eberswalde, Eberswalde-Berlin, 2002, pp. 131-156). 
of the Kaliningrad oblast government, the sanctuary inside the complex was recognised as a cultural monument of regional importance and handed over for use to the Russian Orthodox Church in 2010. Since 2014, however, as appears from images and descriptions posted on various websites by Internet users, no conservation or renovation works have been undertaken..$^{53}$ Today, the vacant buildings is becoming increasingly dilapidated. It will not be long until the complex, a valuable cultural relic, disappears completely. This would certainly be a pity.

\section{Abstract}

The article is a contribution to the research on the role of architecture in the development of Prussian psychiatry in the nineteenth and early twentieth centuries. The basic research problem is the role and perception of model solutions applied in nineteenth-century asylums located in remote provinces, an excellent example being the former Provincial Treatment and Care Centre in Allenberg. Based on the analysis of archival materials and professional journals, the architecture of the Allenberg asylum is compared to contemporary trends and requirements for asylum architecture. It has been found that the asylum discussed in the study met these requirements, proving that models and modern trends from leading centres rapidly reached distant provinces. To summarise, it can be argued that the asylum complex in Allenberg was a testimony to the development of Prussian and European architectural thought in the service of medicine. Unfortunately, today the former asylum remains in an extremely poor condition and is treated as unwanted legacy rather than a cultural monument.

\section{Bibliography}

Алленберг - психиатрическая больнииа Кёнигсберга. Место с душераздирающим кониом, https://only-travel.club/294-allenberg-psihiatricheskaja-bolnica-kenigsberga-mesto-s-dus herazdirajuschim-koncom.html (accessed: 15 February 2021).

Белинцева И.В., “Архитектурный комплекс бывшей психиатрической лечебницы в Алленберге," in: Калининградские архивы, vol. 9, Калининград, 2011, pp. 35-48.

Белинцева И.В., Архитектура Восточной Пруссии: факты и интерпретации. Калининградская область, Калининград, 2020, pp. 208-216.

Bernhardi C.R., "Provinzial-Irrenheil- und Pflegeanstalt Allenberg bei Wehlau," Allgemeine Zeitschrift für Psychiatrie und psychisch-gerichtliche Medizin, 4 (1854), p. 679.

Bernhardi C.R., "Die Heil- und Pflege-Anstalt Allenberg bei Wehlau in Ostpreussen," Correspondenz-Blatt der Gesellschaft für Psychiatrie und Gerichtliche Psychologie, 1 (5) (1 September 1854), pp. 33-36.

Bręczewska-Kulesza D., Architektura w służbie medycyny. Ewolucja układów architektoniczno-urbanistycznych szpitali dla psychicznie chorych na przykładzie pruskich prowincjalnych zakładów leczniczo-opiekuńczych w XIX i początku XX w., Bydgoszcz, 2020.

Charland L.C., "Science and Morals in the Affective Psychopathology of Philippe Pinel," History of Psychiatry, 12 (2010), no. 1, pp. 38-53.

53 Cf. Алленберг - психиатрическая больнииа Кёнигсберга. Место с душераздирающим кониом, https://only-travel.club/294-allenberg-psihiatricheskaja-bolnica-kenigsberga-mesto-s-dusherazdirajuschim-koncom.html (accessed: 15 February 2021). 
Damerow H., "Zur Geschichte des Neubaues der Ständischen Irren- Heil- und Pflege- Anstalt für die Preuss. Provinz Sachsen bei Halle a. d. S.," Allgemeine Zeitschrift für Psychiatrie und psychisch-gerichtliche Medizin, 1 (1844), pp. 97-112.

Edington B., "The Well-Ordered Body: The Quest for Sanity through Nineteenth-Century Asylum Architecture," CBMH/BCHM, 11 (1994), pp. 375-386.

Gropius in Eberswalde. Martin-Gropius-Bau der Landesklinik Eberswalde, Eberswalde-Berlin, 2002, pp. 131-156.

Förster L., "Über den Bau und Organisation der Irrenanstalten," Allgemeine Bauzeitung, 8 (1855), pp. 318-319.

Fries E. (Dr), "Landes- Heil- und Pflegeanstalt Nietleben bei Halle a. d. S.," in: Deutsche Heilund Pflegeanstalten für Psychischkranke in Wort und Bild, ed. J. Bresler, vol. 2, Halle a. Saale, 1911, pp. 214-217.

Funk A., "Irren-Anstalten," in: Handbuch der Architektur, ed. J. Durm, 4, Halb-Band 5, Heft 2, Darmstadt, 1891, pp. 1-60.

Hoppe F., "Die Pflegeanstalt für geisteskranke Männer zu Tapiau Ostpr.," Psychiatrisch-Neurologische Wochenschrift, 11 (12 June 1904), pp. 101-106.

Körte A., Martin Gropius. Leben und Werk eines Berliner Architekten 1824-1880, Berlin, 2013, pp. 295-296.

Laehr H., Die Anstalten für Psychisch-Kranke in Deutschland, Deutsch-Österreich, der Schweiz und den Baltischen Ländern, Berlin, 1907, pp. 2-3.

Leibbrand W., "Damerow, Heinrich Philipp August," in: Neue Deutsche Biographie, vol. 3. Berlin, pp. 498-499, https://www.deutsche-biographie.de/sfz9242.html (accessed: 20 April 2020).

Peters O., Heino Schmieden. Leben und Werk des Architekten und Baumeisters 1835-1913, Berlin, 2016, pp. 353-355.

Pinel P., Traité médico-philosophique sur l'aliénation mentale, 2nd ed., Paris, 1809, https://gallica. bnf.fr/ark:/12148/bpt6k76576g.texteImage (accessed: 29 March 2020).

Podgórska-Klawe Z., Od hospicjum do wspótczesnego szpitala, Warszawa, 1981, pp. 139-158. Porter R., The Greatest Benefit to Mankind: A Medical History of Humanity, London, 1997.

Roller Ch.F.W., Die Irrenanstalt nach allen ihren Beziehungen, Karlsruhe, 1831.

Römer E., "Irren-Anstalt zu Schwetz," Zeitschrift für Bauwessen, 3-4 (1854), pp. 119-124.

Spott G., "Die Provinzial-Irrenanstalt zu Halle," Zeitschrift für praktische Baukunst, 5 (1854), pp. 153-157.

Shorter E.L., Historia psychiatrii. Od zakładu dla obłąanych po erę Prozacu, Warszawa, 2005.

Stoltenhoff A. (Dr), "Provinzial Heil- und Pflege-Anstalt Kortau bei Allenstein in Ostpreussen," in: Deutsche Heil- und Pflegeanstalten für Psychischkranke in Wort und Bild, ed. J. Bresler, vol. 1, Halle a. Saale, 1912, pp. 176-177.

Titius V., "Zur Geschichte der Heil- und Pflegeanstalt Allenberg bei Wehlau," Wehlauer Heimatbrief, 56 (1996/1997), pp. 56-62.

Viszánik M., Die Irrenheil- und Pflegeanstalten Deutschlands, Frankreichs, sammt der CretinenAnstalt auf dem Abendberge in der Schweiz, vol. 1, Vienna, 1845, pp. 67-71.

Daria Bręczewska-Kulesza, dr, assistant professor in the Department of Architecture and Urban Studies of the Technical University in Bydgoszcz. Research interests: architecture, history, and culture of the nineteenth and early twentieth centuries.

(daria.breczewska-kulesza@utp.edu.pl) 